\title{
Vitamin A absorption in cystic fibrosis: risk of hypervitaminosis $\mathrm{A}$
}

\author{
D R James, G Owen, I A Campbell, M C Goodchild
}

\begin{abstract}
Vitamin A status was examined in nine adult cystic fibrosis patients and six adult control subjects, together with an assessment of their ability to absorb $10000 \mathrm{IU}$ of retinyl palmitate from a test meal, taken with appropriate pancreatic enzyme supplements. Median baseline values for plasma retinol and carotene, as well as median serum retinol binding protein concentrations, were significantly lower in cystic fibrosis patients than in control subjects. One cystic fibrosis patient had a raised fasting plasma retinyl ester concentration suggestive of chronic hypervitaminosis $A$, but no symptoms of toxicity. Measures of vitamin A absorption were also significantly lower in cystic fibrosis patients, although there was considerable overlap with control values. No correlation was observed between measures of baseline status and vitamin $A$ absorption. Measurement of plasma retinyl esters may be an appropriate investigation in those patients considered to be at risk of chronic hypervitaminosis $\mathbf{A}$.
\end{abstract}

Pancreatic exocrine insufficiency is usual in cystic fibrosis ${ }^{12}$ and it is not surprising that low serum concentrations of fat soluble vitamins, particularly $A$ and $E$, have been observed. ${ }^{3}$ Low serum vitamin $\mathrm{A}$ concentrations may not be the result of malabsorption alone, as increased liver concentrations of vitamin A with low serum concentrations were reported by Underwood and Denning in $1972 .^{+}$Even with oral vitamin supplements, however, serum concentrations in cystic fibrosis patients remain below those of control populations. ${ }^{+5}$

Chronic hypervitaminosis A may exist for many years among members of the general public without recognition, ${ }^{6}$ resulting eventually in hepatocellular damage and hepatic fibrosis. ${ }^{7}$ Pre-existing liver disease may also affect the capacity of the organ to transport the vitamin into the circulation, thus potentiating its hepatotoxicity. As cystic fibrosis is a condition predisposing to liver pathology, it is not certain that supplementation of all patients with vitamin $A$ is advisable. Doses of vitamin A need not be large to cause toxicity, as this has occurred with oral intakes of 20-45000 IU/day. ${ }^{8}$ Raised plasma retinyl ester concentrations and biochemical evidence of liver damage have been reported in normal control subjects taking moderate doses only (10000 IU or less daily) of the vitamin. ${ }^{9}$ It has been recommended that cystic fibrosis patients be supplemented with 10-25000 IU/ day, ${ }^{10}$ but little is known of how well these supplements are absorbed. Previous studies have examined the absorption of vitamin $\mathrm{A}$ in a fasting state, using a high dose (approximately $7000 \mathrm{IU} /$ $\mathrm{kg}$ body weight) vitamin $\mathrm{A}$ absorption test without pancreatic enzyme supplements. ${ }^{\prime}$

In this study the absorption of 10000 IU vitamin A was examined in a group of adult cystic fibrosis patients who took a test meal, and pancreatic enzyme supplements as they judged appropriate.

\section{Methods}

\section{SUBJECTS AND SAMPLES}

Nine adult cystic fibrosis patients (seven men; median age 22 years (range 16-29)) and six control subjects (three men; median age 27 years (range 19-30)) took part in the study. All cystic fibrosis patients had been taking regular vitamin A supplements and all but one used pancreatic enzyme supplements regularly.

After an overnight fast (cystic fibrosis patients had been asked to omit vitamin supplements from mid-day on the day before the test) samples were taken for the assessment of vitamin A status, plasma retinol and retinyl esters, retinol binding protein, and prealbumin. Samples were also obtained for total plasma carotenes, C reactive protein, and their biochemical profile (albumin, aspartate transaminase, $\gamma$ glutamyl transferase, alkaline phosphatase, and bilirubin).

A test meal consisting of $30 \mathrm{~g}$ cornflakes, 200 $\mathrm{ml}$ whole cow's milk, $120 \mathrm{~g}$ white bread, $20 \mathrm{~g}$ strawberry jam, $5 \mathrm{~g}$ sugar, and $10000 \mathrm{IU}$ vitamin A (as retinyl palmitate, supplied by Hoffman LaRoche, UK) in $1 \mathrm{ml}$ arachis oil was eaten with pancreatic enzyme supplementation where appropriate. Hourly samples for plasma retinyl ester estimation were taken over the following six hours. All subjects were fasted during the study, but allowed free access to water. Cystic fibrosis patients also completed a questionnaire detailing regular medication, bowel function, and symptoms of hypo/hypervitaminosis $\mathrm{A}$, as described elsewhere. ${ }^{11} 12$ They were also asked to undertake a Pancreolauryl test, again using whatever pancreatic supplements they considered necessary.

\section{MATERIALS}

Retinol, retinyl acetate, and retinyl palmitate were obtained from Sigma Chemical Company, Poole, UK, and purified as necessary by alumina column chromatography. All other chemicals and solvents were obtained from $\mathrm{BDH}$ Chemicals Ltd, Poole, UK, and were Analar or high performance liquid chromatography (HPLC) grade as appropriate. Plasma retinol was analysed by an isocratic reverse phase HPLC method, based on those previously described by 
TABLE Biochemical data in control subjects and cystic fibrosis patients taking part in vitamin A absorption study

\begin{tabular}{|c|c|c|c|c|c|c|c|c|c|c|c|c|c|c|c|c|c|}
\hline & \multicolumn{7}{|c|}{ Control subjects } & \multicolumn{10}{|c|}{ Cystic fibrosis patients } \\
\hline & 1 & 2 & 3 & 4 & 5 & 6 & Median & 1 & 2 & 3 & 4 & 5 & 6 & 7 & 8 & 9 & Median \\
\hline Age ( & 30 & 30 & 24 & 27 & 19 & 27 & 27 & 21 & 22 & 1 & 16 & 29 & 23 & 22 & 25 & 24 & 22 \\
\hline albumin $(g / 1)$ & 46 & 44 & 42 & 47 & 45 & 43 & 4 & 4 & 4 & 4 & & 2 & 4 & 39 & 42 & 43 & $41^{\star}$ \\
\hline $\begin{array}{l}\text { Serum aspartate transaminase } \\
(I U / 1)\end{array}$ & 3 & 2 & 28 & 2 & 16 & 29 & 25 & 103 & 1 & 4 & 56 & 47 & 2 & 19 & 18 & 1 & 2 \\
\hline \multirow{2}{*}{$\begin{array}{l}\text { Serum glutamyl transferase } \\
(\mathrm{IU} / \mathrm{l})\end{array}$} & & & & & & & & & & & & 47 & & & & & \\
\hline & 18 & 11 & 9 & 15 & 6 & 11 & 10 & 113 & 26 & 61 & 21 & 92 & 13 & 25 & 16 & 20 & $23^{\star}$ \\
\hline $\begin{array}{l}\text { Serum alkaline phosphatase } \\
\text { (IU/l) }\end{array}$ & 79 & 48 & 48 & 80 & 59 & 86 & 69 & 214 & 90 & 164 & 354 & 195 & 99 & 109 & 166 & 124 & $164^{\star}$ \\
\hline \multirow{5}{*}{$\begin{array}{l}\text { Serum bilirubin }(\mu \mathrm{mol} / \mathrm{l}) \\
\text { Plasma retinol }(\mu \mathrm{mol} / \mathrm{l}) \\
\text { Plasma retinol esters }(\mathrm{nmol} / \mathrm{l}) \\
\text { Serum retinol }(\mathrm{mg} / \mathrm{l}) \\
\text { Serum PA }(\mathrm{mg} / \mathrm{l}) \\
\text { Plasma carotenes }(\mu \mathrm{mol} / \mathrm{l}) \\
\text { Daily vitamin } A \text { supplements }\end{array}$} & 10 & 9 & 10 & 12 & 17 & 17 & 11 & 19 & 5 & 9 & 10 & 21 & 10 & 5 & 12 & 5 & 10 \\
\hline & $2 \cdot 39$ & $\Rightarrow \quad 1 \cdot 72$ & $2 \quad 1 \cdot 14$ & $4 \quad 1.62$ & 1.59 & $\begin{array}{l}1.59 \\
48\end{array}$ & 1.61 & $1 \cdot 23$ & 0.93 & 1.07 & $1 \cdot 23$ & $0 \cdot 86$ & $1 \cdot 37$ & $1 \cdot 00$ & $0 \cdot 65$ & $1 \cdot 19$ & $1 \cdot 04^{\star}$ \\
\hline & $\begin{array}{l}65 \\
50\end{array}$ & $\begin{array}{l}80 \\
40\end{array}$ & $\begin{array}{l}21 \\
26\end{array}$ & $\begin{array}{l}21 \\
40\end{array}$ & $\begin{array}{l}30 \\
41\end{array}$ & $\begin{array}{l}48 \\
34\end{array}$ & $\begin{array}{l}39 \\
38\end{array}$ & $\begin{array}{l}28 \\
28\end{array}$ & $\begin{array}{l}17 \\
25\end{array}$ & $\begin{array}{l}17 \\
28\end{array}$ & $\begin{array}{l}26 \\
37\end{array}$ & $\begin{array}{r}0 \\
23\end{array}$ & $\begin{array}{l}37 \\
33\end{array}$ & $\begin{array}{l}11 \\
25\end{array}$ & $\begin{array}{r}0 \\
22\end{array}$ & $\begin{array}{r}303 \\
35\end{array}$ & $\begin{array}{l}17 \\
28+\end{array}$ \\
\hline & 317 & 314 & 165 & 316 & 269 & 234 & 292 & 204 & 186 & 205 & 238 & 223 & & 168 & 169 & 262 & 205 \\
\hline & $2 \cdot 67$ & $7 \quad 3.53$ & $3 \quad 2.60$ & $0 \quad 2.54$ & 1.82 & $2 \quad 2.53$ & 2.57 & - & 0.34 & 0.40 & $2 \cdot 30$ & 0.36 & $0 \cdot 29$ & 0.35 & 0.29 & 0.91 & $0.36^{\star}$ \\
\hline$\left(\right.$ IU $/$ day $\left.\times 10^{3}\right)$ & - & - & - & - & - & - & - & 16 & $2 \cdot 5$ & 5 & 5 & 13 & 13 & 8 & 8 & 41 & 8 \\
\hline$\Delta$ Retinol esters $(\mathrm{nmol} / \mathrm{l})$ & 160 & 345 & 361 & 78 & 520 & 477 & 353 & 70 & 145 & 206 & 64 & 22 & 172 & 47 & 133 & 266 & $133 \dagger$ \\
\hline curve (nmol.1. $\left.{ }^{-1} \cdot \mathrm{h}\right) \mathrm{l}$ & 1088 & 1368 & 1115 & 237 & 1681 & 650 & 1102 & 193 & 203 & 625 & 193 & 67 & 437 & 145 & 330 & 625 & $203^{\star}$ \\
\hline Lipa & - & - & - & - & - & - & - & 30 & 20 & 10 & 8 & 104 & 32 & 0 & 15 & 112 & 20 \\
\hline Pancreolauryl test result (\%) & - & - & - & - & - & - & - & 6 & 11 & 7 & 6 & 1 & 7 & l & 3 & 7 & \\
\hline
\end{tabular}

${ }^{\star} \mathrm{p}<0.01$ compared with controls; $+\mathrm{p}<0.05$ compared with controls: Mann-Whitney U test.

McClean et al ${ }^{1+}$ and Bieri et al. ${ }^{15}$ Plasma retinyl esters were determined by a modification of the method of Bankson et al. ${ }^{16}$ Serum retinol binding protein was determined by Mancini radial immunodiffusion using commercially available plates and standards (Behring Diagnostics, Hounslow, UK), and prealbumin by rate nephelometry (Beckman Auto-ICS) with Beckman reagents and standards. Plasma carotenes were measured spectrophotometrically. ${ }^{17}$ Samples for the Pancreolauryl test were analysed in accordance with the manufacturer's instructions.

\section{STATISTICS}

Results were analysed by Spearman's rank order correlation test or Mann-Whitney U test with correction for ties, as appropriate.

\section{Results}

There was no significant difference in the age distribution of the patients and control subjects (Table). Serum C reactive protein concentrations were normal $(<6 \mathrm{mg} / \mathrm{l})$ in six of nine cystic fibrosis patients and not significantly raised $(\leq 10.9 \mathrm{mg} / \mathrm{l})$ in the remaining three.

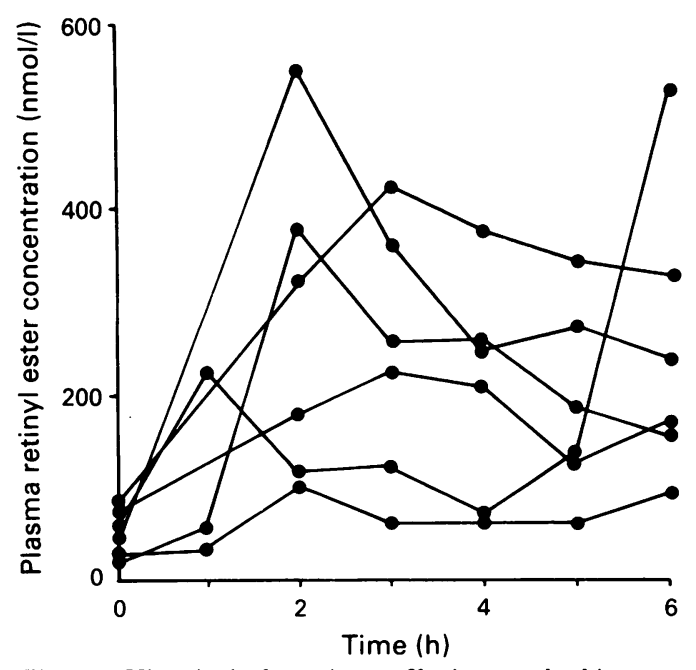

Figure 1: Vitamin A absorption profiles in control subjects.
None of the patients reported symptoms consistent with hypo- or hypervitaminosis A. The median daily quantity of vitamin A supplements taken regularly was $8000 \mathrm{IU}$ (range 2500-41 000 IU); all but one patient (patient 9, who took $41000 \mathrm{IU} /$ day) took $16000 \mathrm{IU} /$ day or less (Table). The median lipase dose (in the form of Creon, Pancrease, Nutrizyme, or Cotazyme) taken with the test meal was 20000 IU (range 0-112000 IU). Some abnormalities of liver function were seen among the cystic fibrosis patients, who also showed lower concentrations of plasma retinol, carotenes, and serum retinol binding protein (Table). No significant difference was observed between the two groups for fasting plasma retinyl ester concentrations (Table).

Measurement of plasma retinyl ester concentrations after the test meal showed that absorption profiles were very variable in both control subjects (Fig l) and cystic fibrosis patients (Fig 2 ). The results of the absorption test are also presented as the maximum rise in plasma retinyl esters ( $\Delta \mathrm{RE})$ and the area under the curve (AUC), the baseline being taken as the fasting value (Fig $3 \mathrm{~A}$ and $\mathrm{B}$ ). The median values in

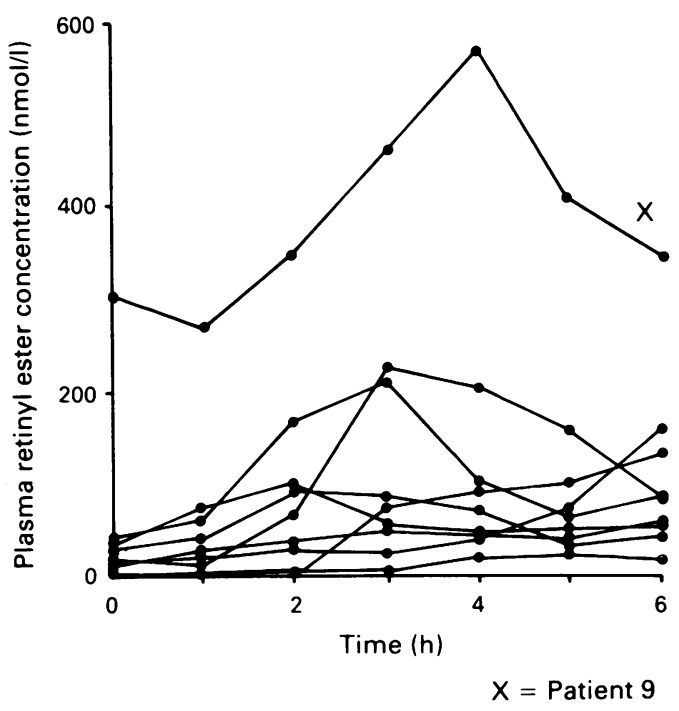

Figure 2: Vitamin A absorption profiles in cystic fibrosis patients. 
cystic fibrosis patients were significantly lower than in control subjects, $(\mathrm{p} \leq 0.05$ for $\Delta \mathrm{RE}$ and $\mathrm{p} \leq 0.01$ for AUC), although there was considerable overlap. No correlations were found between measures of vitamin $\mathrm{A}$ absorption and fasting plasma retinol or retinyl esters.

One patient (patient 9), who had been taking $41000 \mathrm{IU}$ vitamin A/day for at least one year and used large quantities of pancreatic enzyme supplements with meals (112000 IU lipase with the test meal), had a fasting plasma retinyl ester concentration of $303 \mathrm{nmol} / 1$, almost four times greater than that seen in any of the controls (Table). Measures of his vitamin A absorption ( $\triangle \mathrm{RE}$ and AUC) were the highest in the cystic fibrosis group. However, circulating retinol and retinol binding protein concentrations were in keeping with those of the other cystic fibrosis patients. He was a very fit patient who showed no clinical symptoms of hypervitaminosis $\mathrm{A}$, and no evidence clinically or biochemically of liver dysfunction.

Seven patients (including patient 9) undertook the Pancreolauryl test, and all had abnormal
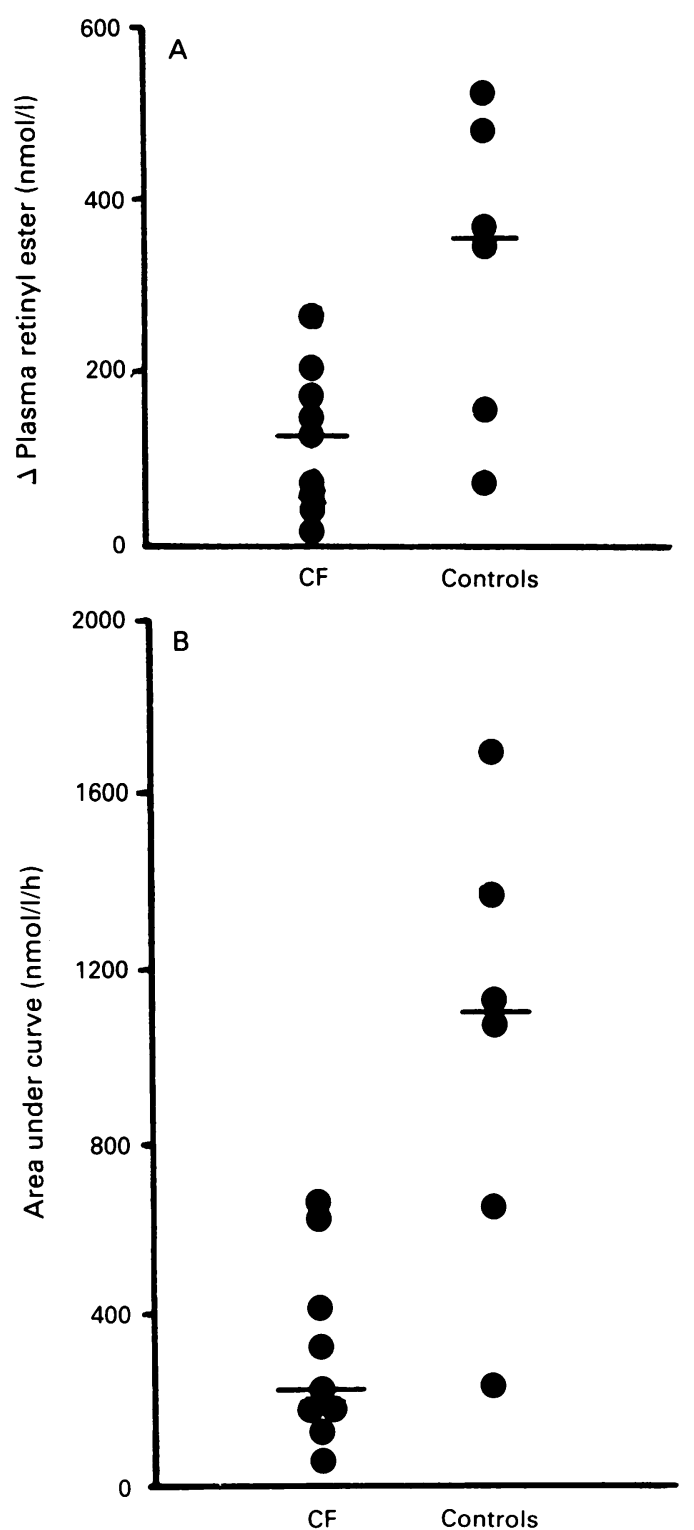

Figure 3: Measures of vitamin A absorption in cystic fibrosis patients and control subjects. (A) Maximum rise in plasma retinol esters: $p<0.05$. (B) The area under the curve: $p<0.01$. results $(<20 \%$, Table). These results, in conjunction with low plasma carotene values obtained in eight of nine patients (Table), indicate that it is very likely that all patients had significant malabsorption. All patients had a clinical requirement for pancreatic enzyme supplements, although these were not well tolerated (and not taken) by one patient (patient 7).

\section{Discussion}

Retinol is absorbed by a carrier mediated passive absorption process under physiological conditions, and by simple passive absorption at pharmacological concentrations. ${ }^{18}$ Absorption is dependent on a number of factors, including the presence of pancreatic enzymes and bile salts. Esterification of the newly absorbed retinol by acyl-Co A: retinyl acyl transferase within the enterocyte is reported to be normal in cystic fibrosis. ${ }^{19}$ The newly esterified vitamin $A$ is then transported to the liver in association with chylomicron remnants. ${ }^{20}$

Observations on baseline vitamin A status of cystic fibrosis patients in this study are similar to those reported in other studies. ${ }^{+5}$ Few data are available on vitamin A absorption in cystic fibrosis, but in our study of nine patients, all of whom had pancreatic insufficiency, some absorbed significant quantities of the preformed vitamin while others did not. It seems that in some patients, mechanisms for vitamin A absorption are not compromised. This wide variation in absorption of vitamin $\mathrm{A}$ is in keeping with observations reported recently on faecal losses of the vitamin in cystic fibrosis. ${ }^{21}$

Acute toxicity results from the ingestion of large quantities of the vitamin over a short period of time, leading to the appearance of free retinol (that is, not bound to retinol binding protein) in the circulation. Persistent consumption of smaller quantities of vitamin A over a prolonged period may result in chronic hypervitaminosis $\mathrm{A}$, with an increase in circulating vitamin $\mathrm{A}$ and in the ratio of ester to alcohol forms."2 The considerably raised fasting plasma retinyl ester concentration of $303 \mathrm{nmol} / \mathrm{l}$ seen in patient 9 (who was taking $41000 \mathrm{IU} /$ day) suggests chronic hypervitaminosis $\mathrm{A}$, although the patient was entirely asymptomatic. Traditionally, chronic hypervitaminosis $\mathrm{A}$ has been associated with an intake of larger quantities of the vitamin (>100000 IU/day) over a prolonged period. However, the daily intake required to produce toxicity is very variable, ranging from $5000 \mathrm{IU}^{23}$ to $1400000 \mathrm{IU},,^{2+}$ and the length of time required is also variable. ${ }^{25}{ }^{26}$ It has also been suggested that there is an inherited variability of susceptibility to vitamin A toxicity. ${ }^{27}$

The toxicity of vitamin A may be modulated by a number of factors, being potentiated by alcohol $^{28}$ and protein-energy malnutrition ${ }^{29}$; a degree of protection is afforded by tocopherol, taurine, and zinc. ${ }^{30}$ In cystic fibrosis the abnormality of vitamin A metabolism seems to be related to an inability of the liver to mobilise its stores of the vitamin, and perhaps it is not surprising that the patient with raised plasma retinyl esters was asymptomatic and had a 
normal plasma retinol concentration. This may be analogous to a report of a non-cystic fibrosis patient who had liver damage from massive vitamin A deposition, together with a depressed serum vitamin A concentration. He had consumed up to $25000 \mathrm{IU} /$ day of the vitamin for seven years and had a degree of protein-energy malnutrition as a result of a poor diet. ${ }^{29}$

Despite having the highest vitamin A absorption parameters, patient 9 ranked only 4 th, 3rd, and 2 nd for plasma retinol, carotenes, and serum retinol binding proteins concentrations respectively. Animal studies suggest that over supplementation may also suppress retinol binding proteins synthesis, ${ }^{31}$ thus further complicating the situation.

Our results suggest that care should be taken with preformed vitamin A supplementation as some cystic fibrosis patients may be at risk of developing hypervitaminosis A if oversupplemented.

The lower plasma carotene concentrations seen in the cystic fibrosis patients suggest that preformed vitamin A supplementation is necessary, as these patients may not be able to meet their daily requirements for this vitamin from dietary carotene alone.

The susceptibility of the liver to injury by increased stores of vitamin A in cystic fibrosis patients, expecially those with liver dysfunction, is not known. It seems prudent therefore to assess in some way the extent of a patient's vitamin A stores, but unfortunately no simple non-invasive technique is available yet. Periodic estimation of fasting plasma retinyl esters seems to be the only option available at present; however, the plasma retinyl ester concentration may be raised only when liver stores of vitamin A are saturated. Further difficulties in interpretation may occur as plasma ester concentrations may be raised as a consequence of liver pathology. ${ }^{16} \mathrm{We}$ are currently investigating the possible use of other vitamin A metabolites as markers of hepatic vitamin A stores.

We are grateful to Dr T J Morris for allowing us to include one of his patients in our study.

1 Di Sant Agnese PA, Talamo RC. Pathogenesis of cystic fibrosis of the pancreas. New Engl F Med 1967; 277: 1399-408.

2 Goodchild MC, Dodge JA. Cystic fibrosis. Manual of diagnosis and management. 2nd ed. Eastbourne, Bailliere Tindall. 1985: 12-5

3 Congden PJ, Bruce G, Rothburn MM, Clarke PCN, Littlewood JM, Kelleher J, et al. Vitamin status in treated patients with cystic fibrosis. Arch Dis Child 1981; 56: 708-14

4 Underwood BA, Denning CR. Blood and liver concentrations of vitamins $A$ and $E$ in children with Cystic Fibrosis. Paediatr Res 1972; 6: 26-31.
5 Knoepfler G, Rotthauwe HW, Odenthal A. Vitamin A carotin, retinolbindendes protein und praealbumin in serum von patienten mit cystischer fibrose. Z Kinderheilkund 1975; 119: 279-91.

6 Stimtson WH. Vitamin A intoxication in adults. Report of a case with a summary of the literature. $N$ Engl F Med 1961 265: 369-73.

7 Russell RM, Boyer JL, Bagheri SA, Hruban Z. Hepatic injury from chronic hypervitaminosis A resulting in portal hypertension and ascites. $N$ Engl F Med 1974; 291: 435-40.

8 Leo MA, Lieber CS. Hypervitaminosis A: a liver lover's lament. Hepatology 1988; 8: 412-7.

9 Krasinski SD, Russell RM, Otradovec CL, Sadowski JA, Hartz SE, Jacob RA, et al. Relationship of vitamin A and vitamin $\mathrm{E}$ intake to fasting plasma retinol, retinol-binding protein, retinyl esters, carotene, $\alpha$-tocopherol; and cholesprotein, retinyl esters, carotene, $\alpha$-tocopherol; and cholesterol among elderly people and young adults: increased plasma retinyl esters among vita

10 Guide to drug therapy in patients with cystic fibrosis. The Cystic Fibrosis Foundation. 1972: 50-2.

11 Warwick WJ, Hausen LG, Sharp H. Absorption of vitamin A in patients with cystic fibrosis. Clin Pediatr 1976; 15: 80710 .

12 Underwood BA. Vitamin A in animal and human nutrition In: Spom MB, Roberts AB, Goodman DS, eds. The retinoids. Vol l. London: Academic Press, 1984: 338-42.

13 Koerner WF, Voellm J. New aspects of the tolerance of retinol in humans. Int $\mathcal{F}$ Vitam Nutr 1975; 45: 363-72.

14 McClean SW, Warwick WJ, Ruddell ME, Gross EG, De Giovanna JJ, Pack GL. Liquid chromatographic assay for Giovanna JJ, Pack GL. Liquid chromatographic assay for
retinol (vitamin A) and retinol analogues in therapeutic retinol (vitamin A) and retinol analo

15 Bieri JG, Tolliver TJ, Catignani GL. Simultaneous determination of $\alpha$-tocopherol and retinol in plasma or red cells by high pressure liquid chromatography. Am F Clin Nutr 1979 32: 2143-9.

16 Bankson DD, Russell RM, Sadowski JA. Determination of retinyl esters and retinol in serum or plasma by normal phase liquid chromatography: method and applications. Clin Chem 1986; 32: 35-40.

17 Gowenlock AH, ed. In: Varley's practical clinical chemistry. 6th ed. London, Heineman. 1988: 895-9.

18 Hollander D. Intestinal absorption of vitamin A, E, D and $\mathrm{K}$. f L ab Clin Med 1981; 97: 449-62.

19 Rasmussen M, Michaelson H, Lie SO, Nilsson A, Petersen LB, Norum KR. Intestinal retinol esterification of serum retinol in children with cystic fibrosis. $\mathcal{F}$ Pediatr Gastroenterol retinol in children with cys

20 Goodman DS, Huang HS, Shiratori T. Tissue distribution and metabolism of newly absorbed vitamin A in the rat. $\mathcal{F}$ Lipid Res 1965; 6: 390-6.

21 Ahmed F, Ellis J, Murphy J, Wootton S, Jackson AA Excessive faecal losses of vitamin A (retinol) in cystic fibrosis. Arch Dis Child 1990; 65: 589-93.

22 Smith FR, Goodman DS. Vitamin A transport in human vitamin A toxicity. $N$ Engl F Med 1976; 294: 805-8.

23 Schurr D, Herbert J, Habibi E, Abrahamov A. Case report: unusual presentation of vitamin A intoxication. $\mathcal{F}$ Paediatr Gastroenterol Nutr 1983; 2: 705-7.

24 Fleischmann R, Schlote W, Schomerus H, Wolburg $\mathrm{H}$ Castrillon-Oberndoffer WL, Hoensch H. Kleinotige Leberzirorrhose mit ausgeprater portaler hypertension als Leberzirorrhose mit ausgeprater portaler hypertension als
Folge einer Vitamin-A Intoxication bei PsoriasisFolge einer Vitamin-A Intoxication bei Psoria

25 Bush ME, Dahms BB. Fatal hypervitaminosis in neonate. Arch Pathol Lab Med 1984; 108: 838-42.

26 Eaton ML. Chronic hypervitaminosis A. Am J Hosp Pharm 1978; 35: 1099-102.

27 Carpenter TO, Pettifor JM, Russell RM, et al. Severe hypervitaminosis A in siblings: Evidence of variable tolerance to retinoid intake. 7 Paediatr 1987; 111: 507-12.

28 Leo MA, Arai Sato M, Lieber CS. Hepatotoxicity of moderate vitamin A supplementation in the rat. Gastroenterology 1982; 82: 194-205.

29 Weber FL Jr, Mitchell GE Jr, Powell DE, Peiser BJ, Banwell JG. Reversible hepatoxicity of moderate vitamin A accumuJG. Reversible hepatoxicity of moderate vitamin A accumu-
lation in a protein deficient patient. Gastroenterology 1982 ; 82: 118-23.

30 Pasantes-Morales H, Wright CE, Gaull GE. Protective effect of taurine, zinc and tocopherol on retinol-induced damage in human lymphoblastoid cells. F Nutr 1984; 114: 2256-61.

31 Mallia AK, Smith JE, Goodman DS. Metabolism of retinolbinding protein and vitamin A during hypervitaminosis $\mathrm{A}$ in the rat. F Lipid Res 1975; 16: 180-8. 